\title{
4
}

\section{BROADER ASSOCIATIONS}

In 1930 Gold Mines of Australia Limited was established in London at the initiative of WS Robinson in conjunction with his brother's stockbroking firm, Lionel Robinson, Clark \& Co. The syndicate that formed the company included The Zinc Corporation and Imperial Smelting Corporation, with New Consolidated Gold Fields having a major interest, along with an associated company, Camp Bird. ${ }^{1}$ Gold Mines of Australia was designed to undertake large-scale exploration for gold and facilitate potential mine developments in Australia. It was one of the principal companies, along with Gold Exploration and Finance Company of Australia, that pursued multiple investments in mining ventures across Australia and which led to the formation of Western Mining Corporation. New Consolidated Gold Fields was a key participant in the early years, not only as a financier but also in taking a role in reviewing mining prospects. As such, it was ideally placed to take advantage of broader associations in Australia for the pursuit of its mining interests in the country.

Lindesay Clark, who in 1931 became manager of Gold Mines of Australia and technical managing director of Western Mining Corporation at its formation in 1933, recalled that, in its first two years, Gold Mines of Australia considered over 200 proposals for mining ventures. ${ }^{2}$ John Agnew and CO Lindberg, a mining engineer and head of The Gold Fields American Development Company, reviewed a number of these

1 Gold Mines of Australia Limited, 'List of Shareholdings as at 25 October 1932' and 'List of Shareholdings as at 17 January 1943', University of Melbourne Archives (UMA), Stock Exchange of Melbourne, 1968.0018, Box 99. The initial shareholding was dominated by companies controlled by Consolidated Gold Fields of South Africa, with New Consolidated Gold Fields having a 60 per cent shareholding (Clark, Built on Gold: Recollections of Western Mining, p. 3).

2 Ralph, 'Clark, Sir Gordon Colvin Lindesay (1896-1986)'. 
prospects. Gold Mines of Australia's initial interests included options related to the Mount Coolon Gold Mine in Queensland, in which Gold Fields was entitled to a one-third interest; Mount Triton Gold Mine, Western Australia; and evaluation of gold opportunities associated with the Berry Leads alluvial system near Ballarat in Victoria. To accommodate the spread of potential activities, a new company, Western Mining Corporation, was incorporated in London in 1933. WS Robinson was again influential in garnering both technical and financial resources, with the shareholding in London including New Consolidated Gold Fields, its associate Camp Bird, and two South African gold mining companies, The Central Mining and Investment Corporation Limited and Union Corporation Limited. North Broken Hill and Broken Hill South were the major Australian shareholders.

The intention was for Gold Mines of Australia to manage all interests in eastern Australia, while Western Mining Corporation would manage Western Australian interests. Agnew was on the London Advisory Committee of Western Mining Corporation. He stepped down due to pressures of work in 1935 and Robert Annan took his place. Western Mining Corporation's early areas of focus included gold properties at Norseman, Mount Magnet, Southern Cross and Kalgoorlie. By 1935 the company was acting as general manager for Gold Mines of Kalgoorlie, Triton Gold Mines, Central Norseman Gold Corporation and Central Yellowdine Gold Mine. ${ }^{3}$ To manage the financing of the two companies, Gold Exploration and Finance Company of Australia was incorporated on 21 June 1934, which in turn had a controlling interest in Western Mining Corporation. New Consolidated Gold Fields had an initial 22 per cent shareholding in this company, with both Agnew and Annan serving as directors. Agnew assumed the chairmanship of the board at Gold Exploration and Finance Company's fourth board meeting, on 15 August 1934. His son, Dolph, attended at least one board meeting as his alternate. ${ }^{4}$

3 Western Mining Corporation, 'Balance Sheet at 31st March, 1934 and Reports for the Period Ended 31st March 1934', UMA, Stock Exchange of Melbourne, 1968.0018, Box 343.

4 'Minutes of Fourth Meeting of the Board of Directors of Gold Exploration and Finance Company of Australia Limited, 15 August 1934'; 'Minutes of Eighth Meeting of the Board of Directors of Gold Exploration and Finance Company of Australia Limited, 8 November 1934', UMA, Western Mining Corporation, 2012.0015, Unit 215. 

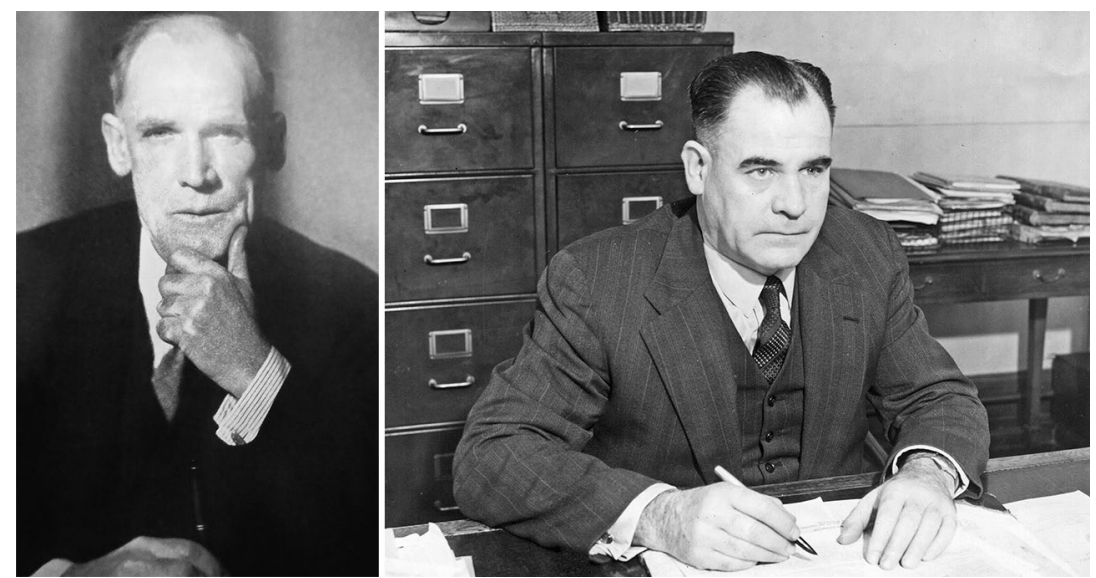

Figures 17 and 18. Father and son engineers: John A Agnew, chairman of The Consolidated Gold Fields of South Africa and influential in the company's early investments in Western Australia and New Guinea, and Dolph Agnew, chairman of Gold Fields Australian Development Company.

Source: Image of John Agnew reproduced from Consolidated Gold Fields of South Africa, The Gold Fields 1887-1937.

Source: Image of Dolph Agnew courtesy of Delia Buchan.

Annan also served as a director, as well as being on the board of Gold Mines of Kalgoorlie, a company that was floated by Gold Exploration and Finance Company in October 1934. ${ }^{5}$ Apart from its controlling interest in Western Mining Corporation (94 per cent) and Gold Mines of Kalgoorlie, Gold Exploration and Finance Company had shareholdings in a range of other mines while Agnew was on the board. ${ }^{6}$ The association with Gold Fields was of importance to the future plans of this Collins Housesponsored group of companies. Colin Fraser, the chairman of Western Mining Corporation, in his address to the 1934 annual general meeting, referred to the assistance provided 'particularly by our friends connected

5 Gold Mines of Australia and Gold Mines of Kalgoorlie, National Library of Australia, MS 10353-Western Mining Corporation Online History Collection/Series 4/Subseries 4.02/Items 4.02.038 and 4.02.039. It is noteworthy that in a Western Mining Corporation publication, both John Agnew and Robert Annan are listed, given their roles as directors of Consolidated Gold Fields of South Africa on Western Mining Corporation-related companies (Ralph, Biographical Sketches of Some Former WMC People).

6 These included the Champagne Syndicate, Costerfield Gold-Antimony mine, Victoria Deep Leads, Nell Gwynne (BML) Mine, Bendigo Mine, Triton Gold Mine and Western Gold Mine (Gold Exploration and Finance Company of Australia Limited, 'Reports and Statements of Accounts for the Period 23rd July 1934 (the date of incorporation) to 31st March, 1935', UMA, Stock Exchange of Melbourne, 1968.0018, Box 98; see also 'Minutes of Meetings of Directors of Gold Exploration and Finance Company of Australia', UMA, Western Mining Corporation 2012.0015, Unit 215). 
with the management of Lake View and Star and Wiluna, the Goldfields Australian Development Co'.7 In the case of Gold Mines of Kalgoorlie, Lake View and Star provided exploration and technical resources, while a mill on the company's Associated leases was made available for use by Gold Mines of Kalgoorlie for treating oxidised and semi-oxidised ores. Ore bodies close to those of Gold Mines of Kalgoorlie also presented the opportunity for joint development by the various interests. ${ }^{8}$

Gold Fields had established itself in an extraordinary position in relation to a number of companies that had the capability to identify mining prospects across Australia. Its connections, both in London and Australia, were second to none. It had established relations with the foremost mining and businessmen in Australia, with Sir Colin Fraser and Sir Walter Massy-Greene serving as the Australian advisory committee of Gold Exploration and Finance Company. ${ }^{9}$ This company, according to Clark, was applying two main methods to Australian gold exploration: aerial photographic surveys and a focus on the evaluation of Precambrian geology. ${ }^{10}$ Even here, Gold Fields was influential, with Annan and Agnew suggesting the introduction of aerial photographic surveys across the eastern goldfields of Western Australia. This was a technique that New Consolidated Gold Fields had used successfully in its geological evaluation of the Witwatersrand area of South Africa in the early 1930s. ${ }^{11}$ Agnew remained an advocate of aerial surveys of mineral depositions throughout his career. While these surveys in Western Australia identified little in terms of mineralisation, the combination of companies remained active in pursuing various mining projects.

While the loose confederation of shared interests and cross shareholdings was a hallmark of the cooperative business approach of the Collins House Group, the model did not prove suitable for Gold Fields. Blainey noted in his research that the big mines of Kalgoorlie were typically directed from

7 Western Mining Corporation Limited, 'Report of Proceedings at First Annual Ordinary General Meeting of Shareholders, held on Thursday, the 30th Day of August, 1934', UMA, Stock Exchange of Melbourne, 1968.0018, Box 343.

8 Gold Mines of Kalgoorlie Limited, 'Reports and Statements of Accounts for the Period 29th October 1934 (date of incorporation) to 31st March 1935', UMA, Stock Exchange of Melbourne, 1968.0018, Box 100 .

9 Kennett, 'Fraser, Sir Colin (1875-1944)'; Lloyd, 'Massy-Greene, Sir Walter (1874-1952)'.

10 For a description of the aerial photographic process, which was conducted over an 11-month period using two De Havilland twin-engine aircraft as well as ground geological survey vehicles, see Hernan, Forgotten Flyer, pp. 113-125.

11 West Australian Mining and Commercial Review, vol. 7, no. 1, 1942, p. 23. 
London while the big Broken Hill mines were directed from Melbourne. ${ }^{12}$ This may have been one reason why this confederation of interests did not survive. Gold Fields' motivations and those of other shareholders soon began to diverge. The divergence was hastened by the presence of the other South African mining houses. As early as 1934, consideration was given at board level to inviting Johannesburg Consolidated Investment Company to participate in the affairs of the companies. Central Mining and Investment Corporation, the largest gold producer in South Africa, and Union Corporation, were introduced to the consortium by Robinson when he sought to expand the focus of Gold Mines of Australia from eastern Australia to Western Australia. All of these South African groups had interests and operations in areas where Gold Fields operated in South Africa.

Agnew, through his knowledge and that of his mining colleagues in Western Australia, believed that Gold Fields had the best insights into the mineral potential of the state. There was little appetite to share this knowledge with South African competitors nor to do so in a company that had been established to progress interests outside Western Australia. Clark believed Gold Fields' motivation was to confine Gold Mines of Australia's exploration activities to eastern Australia and have the affairs of the company managed from London by Gold Fields itself. Such an approach was consistent with the Gold Fields model and capabilities and would have been viewed as an appropriate arrangement to facilitate the expansion of the interests of the British mining group. That it was not readily agreed to and with calls on capital associated with shareholdings across three companies, the London Gold Fields' board became concerned with how its interests-as opposed to those of competing mining companies in South Africa-were being advanced. In this regard, while Clark believed that 'New Consolidated [Gold Fields] accepted the inclusion of the other partners in Australian exploration', he questioned 'whether they were keen to do so'. ${ }^{13}$ When Gold Mines of Australia acquired options for leases at the Norseman field, Western Australia, this was endorsed by Agnew, although on Lindberg's ruling it was rejected. According to Clark:

12 Blainey, The Rise of Broken Hill, p. 83.

13 Clark, Built on Gold: Recollections of Western Mining, p. 23. Clark also addressed this period in an oral interview, National Library of Australia, G Lindesay Clark interview by Alan Hodgart, tape 2, side 2 , session 4 . 
The ... rejection was to have very serious consequences for the group. It resulted, for a time, in losing all connection with the Norseman field ... New Consolidated, through their interest in Lake View and Star Ltd who operated the largest gold mine in Western Australia, presumably wished to preserve this field of exploration for themselves and not bring it into the general pool. Exclusion from Western Australia was not acceptable to W.S. [Robinson] nor, I imagine, to the other South African partners ... New Consolidated's pressure to keep them from the most extensive area of Precambrian rocks known in the country, and therefore the area with the most potential for major mines, was scarcely a proposition the other partners could accept and a split was ... inevitable. ${ }^{14}$

The divergence of interests was intensified when Gold Fields established its own exploration and investment vehicle, Gold Fields Australian Development Company (GFADC), in 1932, even though this company initially had key members of the WS Robinson group of companies as directors. While this company was focused in large part on the opportunities introduced by Claude Albo de Bernales for the extension of the original Wiluna mine, Gold Fields also had an interest in advancing its own wider exploration and gold mining aspirations in Western Australia and elsewhere in Australia. When Robinson obtained an option on the Occidental Syndicate, which became Triton Gold Mines in the Cue Shire of Western Australia, the conflicting aims of the various groups were brought into sharp relief. New Consolidated Gold Fields gradually severed its relations with the Australian group and its shareholdings in the three companies over the period to 1936. In early 1935 Agnew had resigned as a director of Gold Exploration and Finance Company, 'owing to an ever increasing pressure of business'. ${ }^{15} \mathrm{He}$ was replaced by Annan as a director. The respect in which Agnew was held was manifest by the warm 'acknowledgement of the Board's indebtedness to Mr. Agnew for the valuable counsel which he had always made so readily available', while Agnew volunteered his continuing 'advice and opinions ... at the disposal of the Directors on any matter. ${ }^{16}$ Annan resigned as a director a year later in February 1936, at which time the involvement of South African mining groups included Central Mining and Investment Corporation, Union Corporation Ltd and Anglo American Corporation of South Africa.

14 Clark, Built on Gold: Recollections of Western Mining, pp. 23-24.

15 'Minutes of Eleventh Meeting of the Board of Directors of Gold Exploration and Finance Company of Australia Limited, 6 February 1945', UMA, Western Mining Corporation, 2012.0015, Unit 215 .

16 ibid. 
For Clark, the withdrawal of Gold Fields had serious consequences:

It meant the loss to the Group of the valuable Associated Lease at Kalgoorlie, and that funds for the Bendigo venture were not available from one of the possible major contributors. In the original negotiations for amalgamation to form the Champagne Syndicate it was proposed that the Associated Lease, then the property of Lake View and Star, could be transferred for consideration to the new Kalgoorlie venture ... When Gold Mines of Kalgoorlie was formed from the Champagne Syndicate in 1934, New Consolidated withdrew from this proposal and addition of the Associated Lease was refused. This was a great blow to the whole scheme since this lease was by far the most accessible and attractive of the proposed GMK [Gold Mines of Kalgoorlie] titles. ${ }^{17}$

The severing of relations with the expansive mining and secondary processing interests of the Collins House Group of companies may well have also truncated opportunities for New Consolidated Gold Fields, particularly outside Western Australia.

GFADC was incorporated and listed on the London Stock Exchange in 1932 with nominal capital of GB£500,000 and GB£285,000 initially issued. Agnew served as the first chairman. Reflecting the then cooperative arrangements with the WS Robinson companies, Lionel Robinson was a director, with Clive Baillieu, a director of Zinc Corporation, as his alternate. GFADC was majority owned by New Consolidated Gold Fields, with Camp Bird as well as Transvaal Agency, in which Frederic Hamilton had an involvement, also having shareholdings. ${ }^{18}$ GFADC was

17 Clark, Built on Gold: Recollections of Western Mining, p. 24. Katzenellenbogen discusses the role of South African mining interests in the Western Australian gold sector. In relation to Consolidated Gold Fields of South Africa, he observed its importance as a source of funding to Gold Mines of Australia and Western Mining Corporation, writing 'it is clear that Consgold's position not only in London, but in American financial circles as well, placed them in a dominant position and severely restricted the possibilities of Robinson to work without them' (Katzenellenbogen, 'Southern African Mining Interests in Australia’ pp. 127-128).

18 New Consolidated Gold Fields had taken up a debenture issue by Camp Bird and part of the terms of this arrangement was an agreement to provide Camp Bird with the opportunity to take up 10 per cent of any new business interest by New Consolidated Gold Fields (The Times, 15 December 1932). Agnew was responsible for introducing this association, as well as that with Oroville Dredging (to play a role in the New Guinea interests) to Consolidated Gold Fields. Oroville Dredging had been formed in 1909 by FW Baker, who was also involved in the formation of Camp Bird, to acquire the share capital of an American company operating dredges in California and to acquire properties in Colombia (Cartwright, Gold Paved the Way, p. 126; The Mining Magazine, vol. XXVII, no. 1, July 1922, p. 63). 
designed to act as a vehicle for investments in a range of Western Australian gold mines. Principally, though, it was formed to take a shareholding in Moonlight Wiluna Gold Mines, Starlight Gold Mines and Horseshoe Wiluna Gold Mines, comprising leases at the northern end of the field held by Wiluna Gold Mines. Dolph Agnew took charge of the Wiluna mine and the evaluation of the nearby Moonlight Wiluna leases, as well as other mining opportunities following the establishment of GFADC.

The initial focus was on development of the Moonlight Wiluna mine. In 1937, the entire capital of GFADC was called up to take an investment in Yellowdine Investments, which in turn owned 93 per cent of the de Bernales's Yellowdine Gold Development gold mine, near Mount Palmer, west of Kalgoorlie. ${ }^{19}$ In 1938, an interest was acquired in the Kintore Mine at Kunanalling, while options over other deposits in the Coolgardie area, including Spargo's Reward Gold Mine (1935), and Comet gold mine, near Marble Bar, were acquired. The option over the Spargo leases at Coolgardie was terminated in 1937 as an expected extension to the ore body could not be identified. ${ }^{20}$

While Lake View and Star, Wiluna and GFADC operated as separate entities, they had common directors, cross shareholdings and developed joint interests in other gold mining prospects. One observer in 1937 remarked on the 'labyrinth of interlocking interests' when referring to the Yellowdine mine, while Moonlight Wiluna had an interest in the Mount Ida Gold Mine and operated this mine, as well as a one-third interest in Porphyry (1939) Gold Mine. ${ }^{21}$ Interests were also held in some of these mines by Wiluna and Lake View and Star. ${ }^{22}$

19 Western Argus, 28 May 1935; The Advertiser, 25 September 1935; Sunday Times, 19 July 1938; Sunday Times, 9 June 1940. According to the July 1938 Sunday Times article, a de Bernales's associated company, Commonwealth Mining and Finance, held a 46 per cent interest in the Yellowdine mine. 20 Spargo's Reward Gold Mine (1935) No Liability, 'Reports and Statement of Accounts, for the Period 8th April 1936, to 30th June 1937 and Notice of Annual General Meeting', UMA, Stock Exchange of Melbourne, 1968.0018, Box 259. Again, in 1948 the company tried to grant an option to London mining interests to purchase the mine. This could not be executed due to the adverse conditions generally affecting goldmining in Australia'. By this stage the 'finances of the company [were] in a very precarious position' and unless there was a substantial rise in the price of gold 'it may be necessary to consider liquidation of the company'. The company was removed from the official list in 1953, unable to pay its listing fee for that year. It subsequently disposed of its mining equipment (Spargo's Reward Gold Mine (1935) No Liability, The Annual Report of Directors, for the Period Ended 30th June, 1948, p. 1, UMA, Stock Exchange of Melbourne, 1968.0018, Box 259).

21 The Sydney Morning Herald, 31 July 1937.

22 Wiluna Gold Corporation, Limited, 'Directors' Report and Statement of Accounts for the Year Ended 31st March, 1949', UMA, Stock Exchange of Melbourne, 1968.0018, Box 353. 
The decline in the contribution from Wiluna and the short mine life of Moonlight Wiluna led to the consideration of acquiring new mining properties. The chairman of GFADC observed at the 1940 annual general meeting that 'the search for other properties was being prosecuted vigorously' with the most promising being Mount Ida, over which an option had been taken in $1940 .{ }^{23}$ Wiluna, in conjunction with GFADC, also held an option to acquire the Mount Charlotte (Kalgoorlie) Gold Mines. The original two-year option was struck in 1941, which allowed Wiluna to take possession of the Mount Charlotte and Hannan's Hill mines and undertake evaluative work. The outbreak of World War II led the option to be extended, while mining operations at Mount Charlotte were suspended. By 1947, Wiluna recommenced work on evaluation of the mine and extended its option to the end of 1950.

In the period after World War II, the environment for gold mining in Western Australia remained influenced by shortages of labour, rising costs and a fixed gold price, all of which created operational and financial impediments for existing mines and curtailed new investment. Limited Commonwealth Government funding aided some of the larger mines, but support was not available for smaller, more marginal mines. For Gold Fields, Lake View and Star continued to operate profitably as the 'premier mine' in the state but at Wiluna, and in the case of GFADC, there was the challenge of declining ore bodies and the need to replace these with new operations. ${ }^{24}$ In the latter part of 1947 , the re-treatment of accumulated residues from Moonlight Wiluna and Wiluna commenced.

In 1948, Dolph Agnew, while in London, was appointed chairman of GFADC, while also serving as a director of Lake View and Star. He returned to Australia in February 1949 and also assumed the general management role of Mount Ida Gold Mine, which began operations in 1951. While it contributed financially, it had a low level of gold production and small reserves. In 1950, Agnew succeeded Joseph Thorn as general manager of Lake View and Star. He served as vice-president and president of the Chamber of Mines of Western Australia in Perth and Kalgoorlie, and as president of the Australasian Institute of Mining and Metallurgy. He was influential in establishing the Gold Producers' Association and

23 Chemical Engineering and Mining Review, 10 July 1940, p. 389.

24 Government of Western Australia, Report of the Department of Mines for the Year 1948, p. 17. 
the establishment of the Kalgoorlie and Boulder Mines Medical Fund and welfare scheme. ${ }^{25}$ Agnew became an advocate for Gold Fields' interests in Australia and, more broadly, the development of the mining sector in Western Australia. His entreaties to both the Commonwealth Government and state government urged them to do more for the gold sector as it struggled, particularly in the late 1940s as it emerged from the exigencies of the war. ${ }^{26}$

In the 1948 financial year, Wiluna Gold Corporation recorded another loss, while GFADC had accumulated losses that continued through the 1950s, despite generating modest profits in some years. In 1948 Lake George Mines in Australia was converted to a public company, but also experienced the immediate post-war challenges of labour supply, shortage of materials and increasing costs. Development work occurred at Mount Charlotte during 1947 with the shaft enlarged and construction of infrastructure. However, by 1948 the results of the development program were considered disappointing and further expenditure on surface equipment was curtailed. ${ }^{27}$ The option lapsed in 1948, as the mine was assessed as 'unworkable' due to the low grade of ore. ${ }^{28} \mathrm{~A}$ one-third interest in Porphyry (1939) Gold Mine was exercised in 1947 but owing to shortages of labour and scarcity of supplies only a limited amount of work was carried out. In November 1947 underground work was suspended in order to concentrate on the erection of an additional plant. During the 1950s the operation was retained on a care and maintenance basis.

GFADC retained its interest in Moonlight Wiluna and Mount Ida and undertook evaluation of other opportunities, which extended to tin mining in Malaya, but it failed to replenish its portfolio with any material new business interests. ${ }^{29}$ Mount Ida remained the only operating mining

25 West Australian Mining and Commercial Review, vol. 8, no. 1, March 1943, p.14 and vol. 10, no. 9, November 1945.

26 Gold Fields Australian Development Company Limited, 'Report of the Proceedings at the Sixteenth Annual General Meeting of the Company Held at Winchester House, London, E.C., 2 on Wednesday, 10th August, 1949', UMA, Stock Exchange of Melbourne, 1968.0018, Box 99.

27 Chemical Engineering and Mining Review, 10 December 1948, p. 193.

28 Mount Charlotte (Kalgoorlie) Gold Mines Limited, 'To the Members, 1st December 1941' and 'Report of Directors and Statement of Accounts at 31st August, 1948', UMA, Stock Exchange of Melbourne, 1968.0018, Box 181; Gold Fields Australian Development Company Limited, 'Report to the Directors and Accounts for the Year Ended 31st December 1948', UMA, Stock Exchange of Melbourne, 1968.0018, Box 99. In 1955 Mount Charlotte was sold to the Champagne Syndicate, a subsidiary of Western Mining Corporation (Mount Ida Gold Mines Limited, 'Progress Report for the Period to May 31st, 1938', UMA, Stock Exchange of Melbourne, 1968.0018, Box 184).

29 Chemical Engineering and Mining Review, 10 May 1949, p. 304. 
venture for GFADC. Expansion activities were undertaken, with the relocation of equipment from the Moonlight Wiluna mine. The mine exploited the richer Timoni leases and operated through the 1950s, generating modest profits, sufficient to extinguish the accumulated losses of GFADC. ${ }^{30}$ In 1956, the results of underground development work at Mount Ida were deemed disappointing with 'little or no prospect of the mine extending beyond present known limits' and, as such, dependent on drawing down the existing limited reserves. ${ }^{31}$ It continued in operation until 1960. Only Lake View and Star remained a profitable mining operation for Gold Fields, retaining its position as the largest gold producer in Western Australia.

In 1956, New Consolidated Gold Fields (Australasia) (NCGFA) was formed, with authorised capital of $A £ 1$ million with the purpose to undertake exploration activities in Australia, bring projects into production and invest in existing properties. ${ }^{32}$ This was at the time that Mount Ida's reserves were expected to be soon depleted. This entity was in turn fully owned by New Consolidated Gold Fields, the company set up in 1919 to oversee the group's interests outside South Africa. Frank R Beggs was appointed manager and pursued a limited number of ventures, all unsuccessful. ${ }^{33}$ In the period immediately prior to 1960, the prospects for NCGFA were not bright. In 1958 Beggs had identified exploration prospects at Broken Hill and at Mount Isa. A Gold Fields American Development Company representative visited Australia to review each of these. The Mount Isa prospect was further evaluated; it turned out to be an unsuccessful investment and the Broken Hill opportunity also did not amount to anything.

30 Kalgoorlie News, 21 September 1949; The West Australian, 8 July 1954.

31 Chemical Engineering and Mining Review, 11 June 1956, p. 291.

32 'Press Announcement Being Released in London on the 9th August 1956', UMA, Stock Exchange of Melbourne, 1968.0018, Box 206. In 1960, Gold Fields American Development Company, a subsidiary of New Consolidated Gold Fields, initially held the Australian interests before it changed its name to Gold Fields Mining \& Industrial Limited on 5 September 1960. Gold Fields Mining \& Industrial's two Australian subsidiaries included Gold Fields Australian Development Company Limited (65.5 per cent), incorporated on 5 November 1932, which in turn owned the entire share capital of Moonlight Wiluna Gold Mines (Australia), incorporated on 12 October 1931 and that operated the Mount Ida Gold Mine, comprising 11 gold mining leases; and New Consolidated Gold Fields (Australasia) Pty Limited, incorporated 22 August 1956. The Australian-listed companies in which share investments were held were Mining Corporation (Aust) No Liability, Lake George Mining Corporation Limited, and Lake View and Star Limited. Gold Fields Mining \& Industrial subscribed A£1,750,000 or GB£1,400,000 in Commonwealth Mining Investments (representing a 54 per cent interest) and on 29 September 1960 purchased 5,000 North Broken Hill shares (Gold Fields Mining \& Industrial Limited, 16 September 1960, Renison Goldfields Consolidated Archives (RGCA), Box 12300).

33 See Appendix 3 for a biographical profile of Frank Beggs. 
NCGFA invested in Mining Corporation (Australia), listed in 1955, as a way of expanding its exploration interests, in this case for base metals, cobalt and uranium. Two of the initial directors of Mining Corporation were Tom Owen and Ken Craig, individuals who would play a role in the affairs of Consolidated Gold Fields Australia (CGFA) after 1960. Owen was well known to Gold Fields through his involvement with Lake George, serving as operations manager and then chairman. He became an initial director of CGFA while Craig was one of the founders and an initial director of Western Titanium, a company that CGFA acquired in 1969.

In June 1956 the shareholders of Mining Corporation were advised by circular that a drill hole had passed through dolomitic country mineralised with copper. The managing director of the company considered the strike 'so important' to the company that he left for the field 'to examine the position' ${ }^{34}$ Two months later, shareholders of the company were advised that 'offers have been received from important overseas mining groups for a substantial interest in the Company. ${ }^{35}$ By 1957, NCGFA and Pan-American Ventures, a Canadian company, had acquired 47 per cent of the shares of Mining Corporation and appointed two directors, one of whom was Beggs. The company was testing possible southern lateral extensions to the Mount Isa Mine's deposit and conducting other exploration activities, exploring for cobalt, as well as for uranium in Queensland. The new shareholders called an extraordinary general meeting in April 1959 for the purpose of replacing two of the original directors. The non-Gold Fields and Pan-American directors wrote to shareholders expressing concern that 'technical and administrative control' may be assumed by 'two overseas companies' and, in doing so, derail the work being undertaken on the 'brilliant concept on which all our work on Mt Isa is based'. ${ }^{36}$

Beggs conveyed in a letter to a colleague that at 'Mount Isa we have plugged along, watching our cash being thrown down the drain until, finally ... [we] made an agreement ... [to] jointly take control'. ${ }^{37}$ The other directors

34 Mining Corporation (Australia) No Liability, 'Circular to Shareholders, 18th June 1956', UMA, Stock Exchange of Melbourne, 1968.0018, Box 174.

35 'Memo for the Press, Note for Insertion as an Advertisement, 14th August 1956', UMA, Stock Exchange of Melbourne, 1968.0018, Box 174.

36 Mining Corporation (Australia) No Liability, 'Incorporated in May 1955' and 'To The Shareholders, Mining Corporation (Aust.) No Liability, 3rd April 1959', UMA, JB Were and Son, 2000.0017, Box 666 .

37 Letter from Frank R Beggs to Robert T Playter c/- The Gold Fields American Development Company (New York), 27 April 1959, RGCA, 1430, Box 12300. 
had planned to issue themselves with sufficient shares to attempt to retain control of the company. Beggs had foreseen this possibility and obtained a Supreme Court injunction to prevent this. His recollection was that:

We attended a Board Meeting and the opposition were terribly cocky and brought on their motion to issue these shares with broad grins spread all over their faces. Immediately they moved the motion we served the injunctions and I have never seen so many smug grins be so quickly wiped off so many faces. But the extraordinary reaction was that we became the world's biggest ... because we had anticipated that they would do just that. ${ }^{38}$

The change in board composition occurred. Beggs assumed the chairmanship with the addition of another director, mining engineer Keith Addison Cameron, who would be highly influential in the events of CGFA, including as an initial director of the company in $1960 .{ }^{39}$ It was decided to drill two additional holes, with NCGFA advancing the funds. The results were disappointing, and Beggs advised in 1960 that any additional exploration expenditure 'would be of a speculative' nature and not in shareholders' best interests..$^{40}$ Other exploration prospects for Gold Fields in Australia in the late 1950s had also been unproductive. As Beggs wrote forlornly to a colleague in New York:

We are still chasing madly around the country looking at 'mountains of tin' and 'mountains of lead' and 'huge deposits' of just about every kind of mineral there is, and it never ceases to amaze me how these 'huge deposits' shrink to a 6in [6 inch] leader when they are examined. I have never quite been able to make up my mind as to whether the prospectors really think they have a 'mountain' or whether they just build it up in the hope of finding a sucker. ${ }^{41}$

In 1962, SL (Sidney) Segal, the finance director of CGFA, was appointed chairman of Mining Corporation in place of Beggs. Shareholders' funds had been exhausted and loans of $A £ 28,000$ had been incurred,

\footnotetext{
38 ibid., emphasis in original.

39 See Appendix 3 for a biographical profile of Keith Cameron.

40 Beggs called upon Professor KC Dunham of Durham University to report on the company's geological prospects. Durham was later used by CGFA in other capacities, including technical advice on the Mount Goldsworthy iron ore area for Gerald Mortimer (Mining Corporation (Australia) No Liability, Annual Report for the Year Ended 30th June, 1960, UMA, JB Were and Son, 2000.0017, Box 666).

41 Letter from Frank R Beggs to Robert F Playter c/- The Gold Fields American Development Company (New York), 27 April 1959, p. 3, RGCA, 1430, Box 12300.
} 
predominantly from CGFA. Segal advised shareholders that a company that had been granted an option to acquire Mining Corporation's Mount Isa leases had been released from its option. The leases were subsequently sold to Mount Isa Mines in exchange for shares. Even with the sale of these shares, the company's liabilities could not be extinguished and Segal advised shareholders that the company had 'come to the end of the road' and was placed into voluntary administration. ${ }^{42}$

The mining interests of Gold Fields in Australia were in decline. By 1960, Mount Ida had ceased, Lake George was near the end of its economic life and Lake View and Star, aided by the withdrawal of the British tax on foreign entities, continued to contribute dividends to the London parent through to 1970. Dolph Agnew died in July 1960. NCGFA was also not successful. As a consequence, Gold Fields in Australia was unable to recruit experienced mining men to join its ranks and provide a technical base to identify, develop and manage mining ventures. ${ }^{43}$

42 Mining Corporation (Australia) No Liability, Annual Report for the Year Ended 30th June, 1962, UMA, JB Were and Son, 2000.0017, Box 666.

43 An appointment of note made in 1957 was research engineer DF (Douglas) Ainge, formerly of Burma Mining Corporation. 
This text is taken from Consolidated Gold Fields in Australia: The Rise and Decline of a British Mining House, 1926-1998, by Robert Porter, published 2020 by ANU Press, The Australian National University,

Canberra, Australia.

doi.org/10.22459/CGFA.2020.04 